\title{
Journalism-PR relations revisited: The good news, the bad news, and insights into tomorrow's news
}

\author{
Jim Macnamara \\ University of Technology Sydney
}

\begin{abstract}
Extensive research over the past 100 years has shown that the interrelationship between journalism and PR is tensioned and paradoxical, with negative perceptions of PR among journalists and trivialization and demonization of PR as 'spin' contrasted by claims of 'symbiosis' and evidence that 40-75 per cent of media content is significantly influenced by PR. However, studies have been predominantly quantitative and most predate the recent 'crisis in journalism' and rapid growth of new media formats. This article reports in-depth interviews with senior editors, journalists and PR practitioners in three countries that provide new insights into journalism-PR relations today and identify trajectories for future research, education and practice.
\end{abstract}

Keywords: Journalism, PR, spin, media relations, publicity

\section{Introduction}

In 2006, Sallot and Johnson reported that "more than 150 studies have examined some aspect of relations between public relations practitioners as news sources and journalists as media gatekeepers since the 1960s” (2006, p. 151). Public relations and the abbreviation PR are used here to include closely related and largely synonymous roles such as corporate communication, corporate relations and public affairs and focus is on the media relations and publicity functions in these fields of practice. With a number of studies dating back to the early 1900s (Bleyer, 1973), and some conducted since 2006, it is likely that the interrelationship between journalism and PR has been examined in 200 or more research studies. While this may suggest that the interrelationship is well understood, or even over-analyzed as claimed by Smith (2008) in a recent book review, several factors point to a need for further research and analysis.

First, the interaction between journalists and PR practitioners remains paradoxical. While Sallot and Johnson found that some journalists acknowledge a positive contribution from and even "valued" PR (2006, p. 151), most studies have found highly negative perceptions of PR among journalists, as reported in the following literature review. PR is also trivialized, marginalized and demonized in public discourse ranging from criticism in the media and books (e.g., Davies, 2009; Stauber \& Rampton, 1995) to lampooning in TV drama shows and films such as Absolutely Fabulous (Matchett, 2010), Spin City starring Michael J. Fox, and the 2006 Golden Globe nominated movie, Thank You for Smoking. Nevertheless, research studies show that up to 75 per cent of the content of allegedly independent media is sourced from or significantly influenced by PR (see Section 2), prompting some scholars and practitioners to claim that the two fields are "symbiotic" (Bentele \& Northhaft, 2008, p. 35; Currah, 2009, p. 66), "two sides of the same coin" (Evans, 2010), and "mutually dependent" and/or “interdependent” (Erjavec, 2005, p. 163; Gieber \& Johnson, 1961, p. 297).

A second reason for further research is that the vast majority of studies of journalism-PR interrelationships have been based on quantitative surveys and content analysis, which suffer 
from several limitations. In addition to the bias introduced through self-reporting in surveys, which can be significant when feelings run high as they do in the journalism-PR nexus, quantitative studies do not allow in-depth probing of perceptions, relationships, practices and issues of interest. Furthermore, management studies show that survey questionnaires are typically completed by junior to middle level employees, with the most senior and experienced practitioners usually not responding to surveys (Reichheld, 2008, pp. 81-82). This study specifically focused on addressing this limitation through qualitative research among senior practitioners.

The third reason that further research is required is that new media formats and practices are changing the nature of journalism and PR and traditional approaches of media relations and publicity. As Smith (2008) noted, user generated content and social media need to be considered in understanding the influence of PR on media today. New types of 'owned' media enabled by online publishing, which bypass 'gatekeepers', and the development of new sponsored content formats referred to as embedded marketing, native advertising and other terms are potentially increasing the influence of PR and warrant close attention.

\section{100 years of journalist-PR relations research}

\subsection{Highly negative perceptions of $P R$}

While Sallot and Johnson (2006) reported that journalists' recognition of the value of PR increased between 1991 and 2004 and Cameron, Sallot and Curtin concluded that "assumptions of outright animosity may be exaggerated" (1997, pp. 111), numerous studies reveal negative perceptions of and attitudes towards PR (DeLorme \& Fedler, 2003; Jeffers, 1977; Kopenhaver, 1985; Kopenhaver, Martinson \& Ryan; 1984; Ryan \& Martinson, 1988; Sallot \& Johnson, 2006; Stegall \& Sanders, 1986; White \& Shaw, 2005; Wilson \& Supa, 2013). In their historical review of journalist-PR relations, DeLorme and Fedler (2003) concluded that the relationship is "tense and complex" (2003, p. 101). A recent report produced by the Reuters Institute for the Study of Journalism at Oxford University, noted that "in many accounts, PR has been framed as an inherently negative force, a cancer eating away at the heart of modern journalism" (Currah, 2009, p. 62).

Also, professional and popular discourse is fraught with attacks on 'spin' and 'spin doctors' (e.g., Davies, 2009; Ewen, 1996; Stauber \& Rampton, 1995). While the term 'spin' originated in relation to political communication, it is now applied broadly to "any type of commercial PR" (Andrews, 2006; Esser, 2008, p. 4785). PR is also widely described as a "dark art” (Burt, 2012) and "the dark side" by journalists and media professionals (Parker, 2011) and over the years it has been pejoratively labelled "bunco" (Green, 1940; Zolotow, 1949), "ballyhoo" (DeLorme \& Fedler, 2003, p. 103), "boosterism” (Boorstin, 1961), "flack” and "flackery" (Salter, 2005; Stegall \& Sanders, 1986, p. 341), “puff” and "puffery” (Kinnick, 2005, pp. 721723), "hype” (Wilcox \& Cameron, 2006, p. 14) and "propaganda” (Moloney, 2006, p. 41). PR practitioners are accused of being "obstructionists" (Jeffers, 1977; Kopenhaver, Martinson \& Ryan, 1984, p. 860), “shysters” (Sallot, 2002, p 150), "liars” (Cohen, 2009, paras 6, 9), "fakers and phonies" (Blessing \& Marren, 2013, para. 6), and described as "unethical, manipulative, one-sided and deceptive" (DeLorme \& Fedler, 2003, p. 99). In Flat Earth News, Davies accused PR practitioners of being "fabricators" of "pseudo-events", "pseudo-evidence", "pseudo-leaks”, “pseudo-pictures”, "pseudo-illnesses” and “pseudo-groups” (2009, pp. 172193). While some of these criticisms have been identified as results of ignorance (Kopenhaver, 1984), resentment and envy (DeLorme \& Fedler, 2003, p. 113; Sallot \& Johnson, 2006, p. 152), and ideologically based bias in journalism education (Aronoff, 1975; Jeffers, 1977; Stegall \& Sanders, 1986), they nevertheless reflect attitudes and frame interaction. 
PR influence on media content is also problematized as "surreptitious" and lacking transparency, as noted by Cutlip (1994) in his history of PR. In his latest critical media analysis, McChesney warned that media news is "increasingly ... unfiltered public relations generated surreptitiously by corporations and governments” (2013, p. 183).

\subsection{The 'love-hate' relationship}

Based on long-standing anti-PR rhetoric and concerns about PR influence on media among journalists, paradoxically co-existing with high and arguably increasing media usage of PR information, Sallot and Johnson (2006) and Tilley and Hollings (2008) described the interaction as a "love-hate" relationship - a view echoed by Harcup in a contemporary UK journalism text (2009, p. 72). The relationship is also ambiguously described as both "antagonistic” and "symbiotic” (Merkel, Russ-Mohl \& Zavaritt, 2007).

\subsection{More than half of news is $P R /$ 'spin'}

Despite reported perceptions and statements of journalists and editors that suggest noncooperation and hostility, a substantial body of research shows extensive use of PR material by media, referred to as "information subsidies" (Gandy, 1982). A number of such studies have been reported and reviewed elsewhere, such as in DeLorme and Fedler (2003) and, more recently, in Macnamara (2012), so some noteworthy examples only will be summarized here.

In a history of American journalism, Bleyer reported that even before World War I the "system of supplying newspapers with publicity and propaganda in the guise of news became so popular that a census of accredited press agents" was conducted by New York newspapers (1973, p. 421). This identified around 1,200 press agents working to influence public opinion through mass media. Bird and Merwin also noted in their historical review that "the newspaper faced a choice between accepting the releases of press agents, or failing to report many facts needed for the record" (1955, p. 521).

Another early study was conducted in 1926 by Bent (1927) who reported that a systematic analysis of The New York Times found 147 of 256 news stories in the newspaper on December 29 of that year (42.6 per cent) had been suggested, created or supplied by PR practitioners. Only 83 stories were identified as independently generated by journalists and the origin of 26 was uncertain. However, Bent did not analyze sport, society or real estate stories and DeLorme and Fedler observed that all of the 50 real estate stories in the newspaper "seemed to have originated with publicists” (2003, p. 111).

Bixler (1930) reported that women's pages in newspapers were almost totally dependent on publicists and that many stories in business sections were also heavily influenced by PR practitioners, and in 1934 Walker identified 42 of 64 stories in one newspaper "were written or pasted up from press agent material: a little more than 60 per cent” (Walker, 1999, p. 147).

In the 1970s, Sigal classified the sources of 1,146 stories in The Washington Post and The New York Times and found that around 75 per cent resulted from what he called "information processing” as opposed to proactively researched information. Sigal (1973) concluded that around two-thirds of media stories originated from news releases, handouts and other documents handed to reporters by news sources. Later that decade, Gans (1979) reported that 75 per cent of all news came from government and commercial sources, very often as PR 'handouts'.

A number of studies in the 1980s also showed high levels of PR influence ranging from 48 per cent of the content of major newspapers (vanSlyke Turk, 1986) to 59 per cent of news content broadcast by small TV stations (Abbott \& Brassfield, 1989) and up to three-quarters of media 
content overall sourced from PR or official government sources (Whitney, Fritzler, Jones, Mazzarella \& Rakow, 1980).

A large Australian study in the early 1990s found that 768 of 2,500 media stories analyzed (31 per cent) were wholly or substantially based on news releases, including verbatim extracts of statements and facts and figures without alternative attribution. Breakdown by media types showed that 30-40 per cent of the content of national, state and capital city newspapers was based on PR, while around 70 per cent of trade, specialist and suburban media content was PRsourced (Macnamara, 1993).

Another Australian study by Zawawi (1994) confirmed the origin of 683 articles published by three state capital city newspapers and found that 251 (37 per cent) were directly the result of PR activity. Furthermore, Zawawi argued that surveys, papers and submissions sent to journalists with the intent of gaining media coverage could also be regarded as PR and these accounted for a further 88 articles. In total, she concluded that 47 per cent of articles in these major newspapers resulted from PR.

Research shows that substantial PR influence on media content has continued in the twentyfirst century. For example, Sallot and Johnson's (2006) analysis of 413 reports of interviews with US journalists found that journalists themselves estimated that, on average, 44 per cent of the content of US news media was the result of PR contact. Journalists' estimates could be expected to be conservative, given negative attitudes towards PR widely expressed by them in the same survey.

An extensive 2008 study conducted by Cardiff University of 2,207 articles in Britain's leading newspapers and 402 radio and TV reports found that 60 per cent of newspaper stories and 34 per cent of broadcast items was comprised wholly of wire service copy or PR material. The study reported that "a further 13 per cent of press articles and 6 per cent of broadcast news was categorized as 'looks like PR but not found/ongoing'” (Lewis Williams, Franklin, Thomas \& Mosdell, 2008, p. 20). In all, the study indicated that around half of the content of leading British media was shaped in some way by PR (Lewis, et al., 2008).

These and other studies conducted over the past 100 years indicate that $40-75$ per cent of the content of allegedly independent media is routinely sourced from or influenced by PR. Given the negative perceptions of PR among journalists and academic criticisms of the "PR-ization" of media (Blessing \& Marren, 2013; Moloney, 2006, p. 120), a number of important questions remain unanswered, as outlined in Section 3.4.

\section{Addressing the qualitative gap}

A review of the literature shows that most of the studies exploring the interrelationship between journalists and PR practitioners have used quantitative research methods, particularly surveys which rely of self-reporting (e.g., Aronoff, 1975; Cho, 2006; Habermann, Kopenhaver \& Martinson, 1988; Kopenhavere et al., 1984; Ryan \& Martinson, 1984, 1994; Sallot, Steinfatt \& Salwen, 1998; Shin \& Cameron, 2003). Many others have used quantitative content analysis (e.g., Bent, 1927; Curtin \& Rhodenbaugh, 2001; Gans, 1979; Lewis et al., 2008; Macnamara, 1993; Sigal, 1973; Walker, 1999; Zawawi, 1994) and, more recently, Eriksson \& Östman (2013). Some others such as Sallot (2002) have used experiments, administered using questionnaires. While a widely-cited study by White and Shaw (2005) used qualitative textual analysis, it focused on how PR is portrayed in the most commonly used textbooks in introductory mass communication courses, rather than first-hand accounts or observations of practices. These studies all provided useful information, but only a relatively few studies have 
used qualitative research methods such as in-depth interviews or ethnography to look beyond self-ascribed ratings and scores in surveys and quantitative media content analysis. These also have been geographically limited - e.g., an ethnographic study of newsrooms in Slovenia by Erjavec (2005) and a similar study by Sissons (2012) in one city in New Zealand. This study was conducted to provide additional qualitative insights and address the limitation that, notwithstanding Sallot and Johnson's inclusion of "journalists who had worked 18-45 years" (2006, p. 151), surveys are mostly completed by junior to middle level employees and, therefore, do not capture the more informed perceptions and practices of senior experienced practitioners (Reichheld, 2008, pp. 81-82).

\subsection{Methodology}

This study took a qualitative approached based on in-depth interviews. Most interviews were conducted face-to-face and many involved multiple discussions, particularly e-interviews which utilized telephone, Skype or Microsoft Lync conversations and/or multiple e-mail exchanges. All face-to-face interviews, except one conducted in a noisy place, were digitally recorded and transcribed.

\subsection{Sample}

This research began with a pilot study among a purposive sample of information technology and telecommunications (IT) journalists $(n=4)$ and IT sector PR practitioners $(n=5)$ in Australia as an initial exploration of relationships and interactions and to develop and fine-tune an interview question guide for international use. This sector was selected for the pilot study as IT companies are among leading spenders on PR (ICCO \& The Holmes Report, 2013) and the industry is covered by a substantial contingent of specialist media and writers. The pilot study was geographically determined by the researcher's location at the time.

Then, to gain more broad-based and informed insights, 20 interviews were conducted in 2013 with senior editors, journalists and PR practitioners with 20 years or more experience across multiple industries and 'rounds' in the UK, US and Australia. Because these and the nine pilot study interviews were conducted in highly developed countries with Liberal, Social Responsibility, or Democratic Corporatist models of media (Siebert, Peterson \& Schramm, 1954; Hallin \& Mancini, 2004), three further interviews with two journalists working in the Solomon Islands and the senior PR manager for a major aid organization active in the Pacific were included in the study to gain a developmental media and communication perspective (Baran \& Davis, 2009).

Several interviewees had between 30 and 35 years of experience in journalism and/or PR and one had more than 40 years professional experience. A number of interviewees had experience in both journalism and PR, a not unusual occurrence due to the long-standing trend of journalists moving into PR (Lancaster, 1992), and it is considered that this enhanced the sample's insights by affording multiple and comparative perspectives. Overall, the 32 interviewees had an average of 21.5 years of experience in journalism and/or PR, with IT journalists interviewed in the pilot study being younger than others in the sample, which is characteristic of the field. The main sub-sample of 20 interviews had an average of 27 years of experience in journalism and/or PR. As well as ensuring a solid background of practical experience among interviewees, this sampling approach afforded a degree of reflectivity, as most interviewees were aged in their fifties, with several being in their sixties.

As in the pilot study and as is common in qualitative research, purposive sampling was used in main study. This was operationalized by identifying the senior PR/communication professional in or recently retired from a number of large multinational corporations, large government agencies and international PR consultancies across a range of sectors, as well as journalists in 
senior roles in major newspapers and broadcasting networks. The sampling frame prescribed that interviewees were drawn from general news and a range of industry and specialist sectors (i.e., 'rounds' or 'beats') including business and finance, health, energy/petroleum and gas, food, agriculture, consumer products, transport, politics and the non-profit sector, as well as IT and telecommunications.

Openness and frankness were aided by offering anonymity to interviewees - both for their name and their organization's name. However, some were happy to speak on the record, including a number of very senior and experienced PR practitioners and journalists. Interviewees included, for example, the principal deputy assistant secretary of the Office of Public Affairs in the US Department of Homeland Security who previously worked at the White House, as director of communication operations for the US Department of Defense in Iraq and Afghanistan, and with the US Federal Emergency Management Agency (FEMA) in Washington DC - although he made it clear that he was speaking in his personal capacity and not as a representative of any US government agency. Nevertheless, his 30-plus years of experience offered deep insights into domestic and international government media relations. Other senior PR practitioners interviewed included the senior vice-president, corporate affairs of McDonalds (UK/Europe); the former head of PR for British Airways for a decade, the global head of corporate affairs for one of the largest American food and agriculture companies, and the CEOs of a number of the largest global PR agencies. Experienced journalists interviewed included a former executive editor of Britain's top-rating morning TV program, a multi-award winning BBC reporter, a former 'Fleet Street' editor, senior reporters from leading newspapers in the US, a former editor in chief of one of Australia's leading daily newspapers, as well as a number of senior business, finance, technology, health, transport, and media writers and broadcasters in the US, UK and Australia.

\subsection{Data analysis}

Transcripts from interviews and texts such as follow-up e-mails were analyzed using qualitative textual/content analysis techniques based on coding (Shoemaker \& Reese, 1996). Manual coding of interview transcripts and texts was undertaken at two levels. At an initial in vivo or open stage (Glaser, 1978; Punch, 1998), transcripts and texts were coded into 16 broad categories established a priori. A second level of axial coding, also referred to as pattern coding, was then undertaken inductively to identify the specific views, perceptions, practices, concerns, proposals and recommendations that emerged within these categories and reveal patterns and 'clusters' of views (Glaser \& Strauss, 1967; Punch, 1998).

\subsection{Research questions}

This study explored five key inter-related research questions as follows:

3.4.1 How do senior journalists and PR practitioners view each other and their respective roles?

3.4.2 How do journalists and PR practitioner negotiate widely-identified tensions and interact, as research shows they do?

3.4.3 Do journalists and PR practitioners maintain integrity and ethics in dealing with each other and, if so, how?

3.4.4 What, if anything, should be done in journalism and PR education and training to address issues and concerns raised in empirical studies and this research?

3.4.5 What other mechanisms, if any, should be put in place to ensure independence of media content, while maintaining freedom of speech and freedom of the media? 


\subsection{Limitations}

The sample contained a gender skew to men in both journalism and PR, with slightly less than one-third of participants being women. This can be explained to some extent by the focus of the research, which was designed to access the views and experiences of the most senior practitioners. While journalism and PR are now characterized by gender balance in employment, or even a gender imbalance favoring women (Aldoory, 2007; Sha, 1996), practitioners with 25-35 years of experience are more likely to be men, as they reflect recruitment patterns of the 1970s and 1980s.

The sample also included more PR practitioners than journalists and more years of PR experience than years of journalistic experience. The study set out to obtain a balanced mix of journalists' and PR practitioners' views, but the imbalance crept in during conduct of the research project because of a greater reluctance among journalists to be interviewed and comment freely on the topic. Nevertheless, in terms of years of experience, the sample was strongly reflective of both fields, with participants having almost 300 years of journalism experience and slightly more than 400 years of PR experience in total.

\section{Findings}

Despite generalized negative perceptions of PR that persist, this research found some good news for both PR and journalism in terms of their interrelationship and the integrity of media communication overall. However, analysis of extensive discussions with senior practitioners also produced some concerning findings in relation to traditional journalism-PR relations and emergent media practices.

\subsection{PR leaders support independent media, ethics and standards}

Most editors and journalists spoke despondently about the future of journalism, pointing to declining staff numbers resulting in less time for research and writing, which they blamed for high levels of PR content finding its way into media. Far from celebrating the depleted ranks of media gatekeepers and an ostensibly easier path to publication and broadcast of PR material, a number of senior PR practitioners in the US, UK and Australia spoke sincerely about the importance of independent journalism for society. Some expressed grave concerns that a further collapse of journalism and independent media would see governments and disreputable companies operate without adequate checks and balances. For example, the CEO for Europe, Asia and the Middle East (EAME) of one of the world's largest PR consultancies, said:

I respect journalists who have deep integrity ... as a consumer that's what I want. I'm hoping that journalists are looking at multiple sources which include the PR person ... I think if journalism and PR get too cosy, to some extent that doesn't serve the news-reading public (personal communication, June 26, 2013).

In addition to altruistic motives, several PR practitioners interviewed said they have a vested interest in the preservation of independent media, claiming that having information about their organization positively reported in respected independent media was more credible and more impactful than publicity in partisan media or saying it themselves through 'owned' media. While research studies have challenged some assumptions about the value of third party endorsement (e.g., Hallahan, 1999), balanced as well as positive reporting in independent media continues to be seen as important for governments, corporations and other types of organizations - even in the age of proliferating social media. Senior PR practitioners interviewed rejected the notion of 'symbiosis' between journalism and PR and related claims such as the fields being "two sides of the same coin" (Evans, 2010). While they agree that the fields of practice have a significant level of interdependency, senior PR practitioners as well as 
editors and journalists see each field having a distinctly different role and even go as far as arguing that a tension between them is necessary and a sign of health in the media ecosystem.

\subsection{Senior PR and corporate communicators highly respected, effective}

Despite widely reported negative perceptions of PR among journalists, senior editors and journalists took a different tack when asked about PR practitioners with whom they interacted personally. Interviews confirmed previous findings (e.g., Jeffers, 1977) that relationships including strong mutually respectful relationships - are formed between journalists and PR practitioners, particularly those who have known each other over some time. All senior practitioners interviewed identified relationships as important and most journalists acknowledged that they trusted and relied on PR to some extent. The journalists working in a developmental context particularly relied on PR information and support from aid organizations and NGOs. All of five journalists in the information technology and telecommunications field interviewed acknowledged that PR is useful and important to them in achieving their day-to-day professional goals. One said: "My life would be a lot more difficult if it wasn’t for PR people” (personal communication, May 7, 2013). The former editor in chief of a major newspaper group with 35 years of experience in journalism said:

Making contact with the public relations or the public affairs representative of an organization is valuable to your accuracy and to the story generally ... PR practitioners can be very valuable because a journalist may not be exactly up to date with what is the latest law on this or that, or what's the latest developments in an area. The PR practitioner in a specific area will be. He or she is an expert or can direct you to an expert in the organization (personal communication, October 24, 2013).

\subsection{Trivialization, demonization and marginalization of $P R$ continues}

However, despite evidence that editors and journalists admit to positive relationships with and contributions from PR, which was found in this and other research (e.g., Sallot \& Johnson, 2006), a generalized negative discourse about PR continues. While most senior editors and journalists interviewed did not personally participate in such discourse, they acknowledged it is prevalent. For instance, a leading UK journalist who spent a decade as editor of the top-rating morning TV program GMTV in London after previously working for Reuters, Sky News and ITV said: “There's snobbishness, there's an absolute snobbishness in journalism towards PR.” Recounting his time studying journalism at a university which also taught PR, he said:

There was this thing which came from our tutors ... that clearly we were better than public relations people. They were failed journalists. They just didn't have that inquisitive, challenging, ethical, moral part of their backbone (personal communication, June 24, 2013).

A multi award-winning BBC reporter who recently 'crossed over' to work in PR supported this identification of journalism schools in the academy as a source of trivialization, demonization and marginalization of PR, saying:

I can tell you that I did get a negative impression of PR. In fact, one lecturer said that most members of the course would probably end up as PRs as they wouldn't make it as journalists. To him, PR was a second rate profession and this is the perception that many journalists start out with (personal communication, September 2, 2013).

Such views also continue in professional practice. After stating that "journalists are truth seekers, that's what we are”, one of the senior journalists interviewed went on to describe PR practitioners as "sleazy" (personal communication, June 18, 2013). This and other interviewee comments and observations support Jeffers' (1977) finding that journalists generally consider themselves superior to PR practitioners in most respects, including in ethics, social 
consciences, writing skills and even personal morals, and Kopenhaver's research in which she described journalists as "self-righteous” (1984, p. 18).

This raises a puzzling question - how do journalists and editors explain and justify regularly using PR material, relying on PR contacts, and even actively building and maintaining relationships with PR practitioners, while at the same time holding negative perceptions and being highly critical of PR? Probing discussions with senior journalists and PR practitioners in this study revealed two explanations that serve to answer this question and explain the paradox at the heart of the journalism-PR nexus, as reported in the next two key findings.

\subsection{The acculturation of PR practitioners as contacts and trusted sources}

The former BBC journalist turned PR practitioner interviewed said "the best PRs are actually not seen as PRs but as good contacts” (personal communication, October 8, 2013). This prompted close analysis of how journalists describe PR practitioners they know and work with personally as well as PR practitioners and practices generally. As well as confirming the Jeffers Syndrome - the finding by Jeffers (1977) that journalists view PR practitioners who they know personally more favorably than they do PR practitioners generally - this exploration expanded the concept. Beyond regarding some PR practitioners favorably, while denigrating the field generally, this research revealed that for most journalists, some PR practitioners become acculturated into their inner circle of 'contacts' and 'trusted sources'. This process is referred to as acculturation because journalists not only adapt their view of and relationship with such PR practitioners, but they mentally remove them from the field and rubric of PR when they achieve the status of trusted contacts and sources. Other terms used to describe these 'transported' PR practitioners are "specialists" and "experts". For example, when it was pointed out to journalists that one or more of their named sources was a PR practitioner, responses included: "Oh, she's not really a PR, she's more of an industry specialist" and "I don't know what his job title is, but he's an expert in the field”.

Also, a number of senior practitioners working in PR and related roles do not see themselves as $\mathrm{PR}$, or even as one of its synonyms. For instance, the head of communication at the US Department of Homeland Security, who formerly held senior communication roles with the National Security Council based at the White House and with the US State Department and Department of Defense in Iraq and Afghanistan, said he believed he was seen as a "government official" and an "expert" on matters related to security, emergencies and foreign affairs, despite generalized criticism of government 'spin' (personal communication, September 14, 2013).

The former award-winning BBC journalist now transport industry PR head provided further insight into the ambiguous attitudes of journalists towards PR and also provided an explanation of why some journalists deny using PR material when evidence shows that they do, as noted by DeLorme and Fedler (2003, p. 111), Davies (2009, p. 52), and Turner (2010, p. 212). He said "journalists mainly classify PR material as that given in press releases, events and conferences", adding that "many would not classify information gained in briefings and from those they view as 'contacts' as PR material” (personal communication, September 2, 2013). In other words, journalists apply a quite narrow definition of PR and do not recognize many personalized and sophisticated communication strategies, such as briefings, exclusive interviews, arranging access to senior executives and visiting VIPs, information on Web sites, annual reports and special reports, and major events as PR.

A former head of PR for British Airways and Bupa acknowledged that 'educating' journalists about PR would likely be seen as "inviting the fox into a hen house" (personal communication, June 20, 2013), but he and most interviewees - journalists and PR practitioners - agreed that there is a need for education of journalists about PR to equip them to understand and work with 
PR. While 'academic wars' have occurred and continue in some institutions between the fields of journalism, mass communication and PR (White \& Shaw, 2005; Wright, 2005), interviewees agreed that PR education would increase journalists' "ability to identify, analyze and evaluate" PR messages, which Coombs and Holladay refer to as "public relations literacy" (2010, p. 10), as well as disrupt stereotypes and prejudices based on misunderstanding and myths.

\subsection{The dual personality of $P R$}

A related finding that presents the other side of the PR coin is something that widelypropagated normative theories of PR disguise and fail to adequately address and which has implications for PR education. The group corporate communications manager of a major oil company with 14 years of experience in PR after nine years working as a journalist said: "The problem is not PR per se, but in the large number of inexperienced practitioners who have come into PR" (personal communication, August 16, 2013). Several senior PR practitioners commented that the rapid growth of PR in many countries has meant that, for every senior experienced practitioner who is trusted by journalists, there are dozens or hundreds, of young, inexperienced practitioners. The international president of one of the world's top $10 \mathrm{PR}$ agencies bluntly commented:

Can you imagine that, a dozen times a day, someone’s who's 21, who's saying 'did you get my press release?' or 'I've got this ...' [pause to suggest some product or service]. I've no idea who I'm targeting. I don't really understand the paper ... I call on deadline. I think the problem is that many agencies have front line staff that [sic] are speaking to experienced journalists ... you have these junior people who are untrained, just bothering them constantly (personal communication, June 24, 2013).

From a journalistic perspective, the producer of a long-running program on Australia's ABC echoed this criticism, saying "many PRs are unsophisticated. They send out press releases and think they will be used. And then there are the follow-up phone calls. Often these are made by very junior staff” (personal communication, December 3, 2013). The editor of a leading UK media trade journal similarly said: "It's the people at the end of the food chain who are tasked with doing the initial sell in or follow up phone calls to journalists" (personal communication, June 26, 2013).

The director of trade marketing and corporate affairs for a leading media and communications company in Australia at the time of this study refers to young inexperienced practitioners as the "Felicity Publicity" types (personal communication, October 10, 2013), noting that they are increasingly young women as a result of a feminization of PR that has occurred in most countries over the past decade (Aldoory, 2007; Sha, 1996). An editor of a leading media trade journal interviewed similarly referred to "the fluffy bunny end of the market" saying "that's where you get the 22-year old junior trainee deputy acting assistant account executives ringing up. There are a million of them" (personal communication, June 26, 2013) ${ }^{2}$. A former head of PR for British Telecom who also worked as director of corporate relations for the BBC, said that the image and reputation of PR is negatively impacted by journalists' experiences in "dealing with junior PR people, particularly in the smaller consultancies" (personal communication, June 26, 2013).

Comparison of these observations with the previous finding indicates that, despite the ethical, socially responsible and increasingly professionalized conceptualization of PR advanced in Excellence theory and other contemporary PR theories and models (Botan \& Hazelton, 2006; Heath, 2010), PR suffers from what psychiatry previously called Multiple Personality Disorder and is now termed Dissociative Identity Disorder, commonly referred to as a split or dual personality (American Psychiatric Association, 2000, pp. 526-529). While this metaphor is 
drawn from a quite different disciplinary context, and it is not intended to deny myriad variations and diversity in practice, it is useful in identifying two distinctly different identities of PR that exist.

\subsection{The 'poor relation' of media relations}

The previous finding that media relations is often assigned to junior and inexperienced staff has implications for PR practice as well as education and training. Apart from specialist roles and agencies in which technically skilled and experienced practitioners interact with media, continuing strong growth of the PR industry in many countries (ICCO, 2011), which is increasing demand for new recruits, organization structures in which senior practitioners are appointed to management roles, and economics (i.e., keeping costs down) are likely to perpetuate this trend. Therefore, education and ongoing professional development are important to prevent media relations being the ‘poor relation' of PR and further dragging down its reputation as well as media standards.

\subsection{The Pareto Principle of PR}

The scale of this problem for the PR industry is significant, according to senior practitioners interviewed. The head of PR for a major oil company said the PR industry exhibits the classic Pareto Principle. He said that, in some cases, the relationship between PR and media was a case of "a love that dare not speak its name", but he added "that probably applies to only 20 per cent. The other 80 per cent is puff and is not always entirely truthful” (personal communication, August 16, 2013). The senior Australian Broadcasting Corporation producer interviewed said "those who have been around a long time know what to bring me." Unfortunately for the PR industry, those who know what they are doing appear to be outnumbered substantially by those who do not. He added bluntly: "I rarely come across a PR person who knows what they are talking about” (personal communication, December 3, 2013).

\subsection{Social or anti-social media?}

All PR practitioners interviewed see social media as a key channel for communication in future, although all equally see traditional media remaining important, as discussed under 4.1. The former GMTV journalist turned PR practitioner interviewed said: "With being able to go direct to people, you are broadcasting yourself. A lot of what we do here [global PR agency London office] is broadcasting straight to people ... we're plugging into people directly now, bypassing the traditional routes” (personal communication, June 24, 2013). Similarly, the UK/Europe head of corporate affairs of McDonalds said: "PR can now talk directly to audiences rather than going via [traditional] media, so it's holding more and more cards" (personal communication, June 19, 2013). Several PR practitioners interviewed also claimed two-way interaction and dialogue were beneficial affordances of social media, as noted by academic researchers (e.g., Bucy, 2004; Jenkins, 2006).

The US-based vice president of corporate affairs for one of the world's largest agriculture and food companies said "the technology today allows you to go direct in a way that you couldn't before". However, he and several other PR practitioners interviewed see social media as a "leveller" and a "double edge sword". The corporate affairs VP noted that, as well as providing a direct channel for organization-public communication, the ubiquitous nature of social media created transparency in terms of organizational behaviour, quoting his chairman as saying: "In a world where nothing can be hidden, you better not have anything to hide" (personal communication, October 21, 2013). Similarly, the head of communication for the US Department of Homeland Security said: “Today's digital and social media technology have changed how we do business. We are keenly aware that we can't hide the truth (personal communication, September 14, 2013). 
However, notwithstanding theoretical conceptualizations and practitioner claims of increasing dialogue and transparency, research studies indicate that social media are mainly used by PR practitioners as additional channels for one-way transmission of organization messages (McCorkindale, 2010; Wright \& Hinson, 2009). While journalists themselves are increasingly embracing social media, they are sensitive to the increased autonomy and power that have been handed to PR practitioners by the internet and are concerned about being bypassed, leading to misinformation and propaganda corrupting the public sphere. Social media are thus an expanded site of journalism-PR tension and are likely to become more so in light of the further developments discussed in the following sections.

\subsection{New sponsored content strategies test ethics}

The problems and challenges identified by leading practitioners and summarized in the previous sections become doubly significant in light of new developments in media. In the wake of the 'crisis in journalism' caused by collapsing media business models (Curran, 2010; Jones, 2011), many media organizations are open to and actively soliciting new forms of paid media content, which have been labeled "the hoary advertorial dressed up in twenty-first century clothes” (Wasserman (2013, para. 1). These go by a range of names (or euphemisms) including 'paid content', 'content integration', 'editorial integration', 'native advertising' and 'embedded marketing'. The key characteristic of these formats is that they 'embed', so as to partially hide or render invisible, paid promotional messages and products in media content and internet news and information sites. Examples range from paid interviews in traditional media news, talk and lifestyle shows to paid blogs posts and reviews, sponsored content on news sites, and promoted trends on Twitter (Glick \& Neckes, 2013). These forms of content designed to "hide the truth" about their promotional intent (de Pelsmacker \& Neijens, 2012, p. 1) raise serious questions about transparency and ethics for PR and corporate and marketing communication as well as journalism.

While several interviewees had heard of these new developments, none had been involved in them. Nevertheless, most felt that pragmatism - i.e., pressure on PR to reach fragmenting audiences and achieve employers' objectives along with complicit media seeking new revenue streams - would see them grow. Media industry research supports this view (e.g., PQ Media, 2013). In mid-2013 the New York head office of the world's largest PR consultancy firm, Edelman, issued a report titled Sponsored Content: A Broader Relationship with the US News Media that acknowledged "major ethical hurdles" in relation to embedded paid content, but noted that, like many other PR and marketing communication firms, Edelman was "teaming up with the advertising arm of publishers on sponsored content partnerships (Edelman, 2013, p. 2). Edelman committed itself to disclosure of paid media content, (p. 8), but marketing scholars warn that these emergent practices are under-researched and that codes of practice inadequately address them (de Pelsmacker \& Neijens, 2012; Wouters \& de Pelsmacker, 2010, p. 300).

\section{$4.1021^{\text {st }}$ century corporate publishing}

A concept closely related to embedded marketing and its various synonyms is the twenty-first century iteration of corporate publishing. While traditional corporate publishing ('owned media') relied on printed 'house' magazines, newsletters and reports, digitization and the Web not only reduce production costs but, even more significantly, enable direct national and even global distribution. Furthermore, the collapse of traditional media business models based on advertising has resulted in major media companies seeking new revenue streams and lines of business in the field of digital corporate publishing / 'owned media', which further blur the lines between journalism and PR and even create convergence of journalism and PR. Rather than non-media organizations undertaking their own publishing, cash-strapped media companies are offering their journalistic staff and production facilities to companies and 
organizations to publish bespoke digital publications under the editorial direction or even full control of the client organization.

Examples can be seen on the Web site of Atlantic Media, publisher of the prestigious monthly The Atlantic. In addition to its independent publications, Atlantic Media now publishes a number of sponsored digital publications such as Ideas Lab, which is described as "a hub for commentary and debate on issues ranging from education to energy to technology" (Atlantic Media, 2014). Ideas Lab (http://www.ideaslaboratory.com) is "a partnership between GE and Atlantic Media Strategies, a division of Atlantic Media" - a commercial arrangement that is subtly declared on the masthead as "made possible by GE", but in all other respects the publication is presented to look like an independent online magazine produced by the prestigious publisher. Journalists interviewed unanimously expressed concern and alarm about these developments. While the senior PR practitioners interviewed had not engaged in media partnerships for corporate publishing, three reported that they had hired out-of-work journalists in the previous 12 months to produce media content on behalf of their organization and see this as an emerging trend.

Despite concerns expressed about the amount of traditional media content supplied or influenced by PR, as shown in Section 2.3, and these new formats, interviewees unanimously rejected any form of regulatory requirement for disclosure of PR information as called for by some reviews (e.g., Witschge, Fenton \& Freedman, 2010) and other interventions such as licensing of PR practitioners, which was first advocated by Edward Bernays (1992/1993). Both journalists and PR practitioners argued for self-regulation, but neither field of practice offered any specific suggestions to address the lack of transparency in relation to information subsidies' used by journalists and new hybridized PR/advertising/product placement formats and sites of journalism-PR convergence.

\section{Conclusions}

This study found that senior practitioners in both PR and journalism support independent media and reject notions of symbiosis between journalism and PR, instead arguing that, even though they interact, the fields of practice operate independently of each other in many cases and have distinctly different roles, which should not be blurred or converged. In fact, they go further and argue that tension between the fields of practice is a sign of health in a media ecosystem. However, despite expressed good intentions, a number of factors point to a worsening lack of transparency and increasing convergence of journalism and PR

This research confirmed and expanded the Jeffers Syndrome to show that journalists acculturate experienced PR practitioners who they know and deal with frequently into their circle of 'expert' contacts and trusted sources and no longer see them as PR. Many journalists also have a narrow view of PR, seeing it predominantly as news releases and phone calls and emails from PR practitioners other than their contacts/trusted sources. These factors explain the frequent denials by journalists that they use information provided by 'PR' and continuing negative perceptions of PR. For most journalists, PR is propagated by 'others' outside their circle of contacts and sources who try to influence media and comprised of information 'other' than that which they find newsworthy or interesting. These findings build on previous insights into how journalists and PR practitioners view each other and how they negotiate widelyidentified tensions and interact (research questions 3.4.1 and 3.4.2)

In addition, this research identified concerns and a need for change in relation to research questions 3.4.3, 3.4.4, and 3.4.5. Both journalists and senior PR practitioners are concerned about the scale and standards of these 'othered' media relations and publicity practices - albeit 
for different reasons. Journalists see them as a large and growing field of practice corrupting media and the public sphere. Senior PR practitioners see them as an embarrassing 'rump' of the industry compromising the reputation of PR generally.

Furthermore, emergent media practices including organizational social media use and new forms of sponsored media content and online corporate publishing, often through media partnerships, are expanding the horizons of PR and blurring the boundaries of journalism, PR and advertising. While functionalist approaches to PR might see this as an opportunity to take advantage of the weakened state of journalism (Pew Research Center, 2013) and new channels for subsidized media content, a socially responsible view suggests that, more than ever, PR needs to focus on ethics and consider societal as well as organization interests.

These findings suggest that there is an urgent need for education of journalists about PR - a potentially controversial conclusion, but one that is supported by senior editors and journalists interviewed - as well as a need for reinvigorated focus on ethical PR education. At an industry level, there is a demonstrable need for increased commitment to training and professional development of young PR practitioners and to review codes of ethics and codes of practice to keep pace with emergent media practices and formats. These emergent practices and formats are also an area for research engagement by PR scholars who can bring a broader perspective than advertising and marketing considerations which currently inform them.

\section{References}

Abbott, E., \& Brassfield, L. (1989). Comparing decisions on releases by TV and newspaper gatekeepers. Journalism Quarterly, 66(4), 853-856.

Aldoory, L. (2007). Reconceiving gender for an 'excellent' future in public relations scholarship. In Toth, E. (Ed.), The future of excellence in public relations and communication management (pp. 399-411). Mahwah, NJ: Lawrence Erlbaum.

American Psychiatric Association (2000). Diagnostic and statistical manual of mental disorders IV. Arlington, VA: American Psychiatric Publishing.

Aronoff, C. (1975). Credibility of public relations for journalists. Public Relations Review, 1(1), 45-56.

Atlantic Media. (2014). About Atlantic Media Strategies. Retrieved from http://www.atlanticmedia.com/brands/atlantic-media-strategies/

Baran, S., \& Davis, D. (2009). Mass communication theory: Foundations, ferment and future ( $5^{\text {th }}$ ed.). Boston, MA: Wadsworth Cengage Learning.

Bent, S. (1927). Ballyhoo: The voice of the press. New York: Boni \& Liveright.

Bentele, G., \& Nothhaft, H. (2008). The intereffication model: Theoretical discussions and empirical research. In A. Zerfass, B. Van Ruler, \& K. Sriramesh (Eds.), Public relations research: European and international perspectives and innovations (pp. 33-48). Wiesbaden, Germany: VS Verlag fur Sozialwissenschaften (Springer Science + Business Media).

Bernays, E. (1992/1993). The future of public relations: Is licensing the answer? Journal of Corporate Public Relations, 3, 8-10.

Bird, G., \& Merwin, F. (Eds.). (1955). The press and society: A book of readings. New York, NY: Prentice-Hall. (Original work published 1951). Retrieved from http://archive.org/stream/pressandsociety030075mbp/pressandsociety030075mbp_djvu.txt

Bixler, P. (1930). The reporter's last stand. The North American Review, 229, January, 113-116.

Blessing, K., \& Marren, J. (2013). Is the PR-ization of media ... BS? Media Ethics, 24(2). Retrieved from http://www.mediaethicsmagazine.com/index.php/browse-back-issues/145-spring2013/3998865-is-the-pr-ization-of-media-bullshit

Bleyer, W. (1973). Main currents in the history of American journalism. New York: Da Capo Press. (Original work published 1927)

Boorstin, D. (1961). The image: What happened to the American dream. London: Weidenfeld \& Nicolson.

Botan, C., \& V. Hazelton, V. (Eds.), Public relations theory II. Mahwah, NJ: Lawrence Erlbaum. 
Bucy, E. (2004). Interactivity in society: Locating an elusive concept. Information Society, 20(5), 373383.

Burt, T. (2012). Dark art: The changing face of public relations. London, UK: Elliott \& Thompson.

Cameron, G., Sallot, L., \& Curtin, P. (1997). Public relations and the production of news: A critical review and theoretical framework. In B. Burleson (Ed.), Communication yearbook 20 (pp. 111-155). Thousand Oaks, CA: Sage.

Cho, S. (2006). The power of public relations in media relations: A national survey of health PR practitioners. Journalism \& Mass Communication Quarterly, 83(3), 563-580.

Cohen, A. (2009, May 7). The flak over flacks. CBS News, Sunday Morning. Retrieved from http://www.cbsnews.com/stories/2008/06/01/sunday/main4142947.shtml

Coombs, W., \& Holloday, S. (2010). PR strategy and application: Managing influence. Malden, MA: Wiley-Blackwell.

Currah, A. (2009). What's happening to our news. Oxford, UK: Reuters Institute for the Study of Journalism, Oxford University. Retrieved from https://reutersinstitute.politics.ox.ac.uk/about/news/item/article/whats-happening-to-our-news.html

Curran, J. (2010). Future of journalism. Journalism Studies, 11(4), 464-476.

Curran, J. (2011). Media and democracy. Abingdon, Oxon, UK: Routledge.

Curtin, P., \& Rhodenbaugh, E. (2001). Building the news media agenda on the environment: a comparison of public relations and journalistic sources. Public Relations Review, 27(2), 179-195. DOI.org/10.1016/S0363-8111(01)00079-0

Cutlip, S. (1994). The unseen power: Public relations: A history. Hillsdale, NJ: Lawrence Erlbaum.

Davies, N. (2009). Flat earth news. London, UK: Random House.

DeLorme, D., \& Fedler, F. (2003). Journalists' hostility toward public relations: An historical analysis. Public Relations Review, 29, 99-124.

de Pelsmacker, P., \& Neijens, P. (2012). New advertising formats: How persuasion knowledge affects consumer response. Journal of Marketing Communications, 18 (1), 1-4. DOI: 10.1080/13527266.2011.620762

Edelman. (2013). Sponsored content: A broader relationship with the US news media. New York, NY: Author. Retrieved from http://www.edelman.com/insights/intellectual-property/sponsored-contentreport

Eriksson, G., \& Östman, J. (2013). Co-operative or adversarial: Journalists' enactment of the watchdog function in political news production. International Journal of Press/Politics, 18(3), 304-324.

Erjavec, K. (2005). Hybrid public relations news discourse. European Journal of Communication, 20(2), 155-179. DOI: 10.1177.0267323105052295

Esser, F. (2008). 'Spin doctor'. In W. Donsbach, (Ed.), The international encyclopedia of communication (pp. 4783-4787). Malden, MA: Blackwell.

Evans, T. (2010). We are all in PR now. British Journalism Review, 21(2), 31-36. DOI: 10.1177/0956474810374531

Ewen, S. (1996). PR! A social history of spin. New York, NY: Basic Books.

Gandy, O. (1982). Beyond agenda setting: Information subsidies and public policy. Norwood, NJ: Ablex.

Gans, H. (1979). Deciding what's news: A study of CBS evening news, NBC nightly news, Newsweek and Time. New York, NY: Vintage.

Gieber, W., \& Johnson, W. (1961). The City Hall ‘beat': A study of reporter and source roles. Journalism Quarterly, 38, 289-297.

Glaser, B. (1978). Theoretical sensitivity. Mill Valley, CA: Sociology Press.

Glaser, B., \& Strauss, A. (1967). The discovery of grounded theory: Strategies for qualitative research. Chicago, IL: Adline.

Glick, J., \& Neckes, J. (2013, September 22). Native advertising 101: Understanding the native continuum. Gigaom, Roadmap. Retrieved from http://paidcontent.org/2013/09/22/nativeadvertising-101-understanding-the-native-continuum/

Green, J. (1940, September). Crazy like a fox. American Magazine, 130, p. 57.

Habermann, P., Kopenhaver, L., \& Martinson, D. (1988). Sequence faculty divided on PR value, status and news orientation. Journalism Quarterly, 65, 490-496.

Hallahan, K. (1999). No, Virginia, it’s not true what they say about publicity's 'implied third-party endorsement' effect. Public Relations Review, 25(3), 331 -350. 
Hallin, D., \& Mancini, P. (2004). Comparing media systems: Three models of media and politics. New York, NY: Cambridge University Press.

Harcup, T. (2009). Journalism: Principles and practices ( $2^{\text {nd }}$ ed.). London, UK: Sage.

Heath R. (Ed.). (2010). The Sage handbook of public relations $\left(2^{\text {nd }}\right.$ ed.). Thousand Oaks, CA: Sage.

ICCO (International Communications Consultancy Organization). (2011). ICCO world report: A return to growth. Retrieved from

http://www.iccopr.com/fckeditor/editor/filemanager/connectors/aspx/fckeditor/userfiles/file/ICCOW R2011_Return2Growth_final.pdf

ICCO (International Communications Consultancy Organization) and The Holmes Report. (2013).

World PR Report. London, UK: Author. Retrieved from

http://www.slideshare.net/ArunSudhaman/world-reportsmaller

Jeffers, D. (1977). Performance expectations as a measure of relative status of news and PR people. Journalism Quarterly, 54, 299-307.

Jenkins, H. (2006). Convergence culture: Where old and new media collide. New York, NY: New York University Press.

Jones, A. (2011). Losing the news: The future of the news that feeds democracy. In D. Graber (Ed.), Media power in politics (pp. 57-65). Washington, DC: CQ Press.

Kinnick, K. (2005). Puffery. In R. Heath (Ed.), The encyclopedia of public relations Vol. 2. Thousand Oaks, CA: Sage.

Kopenhaver, L. (1984). Local journalists teach PR students about news ethics. Journalism Educator, 39(3), 17-19.

Kopenhaver, L. (1985). Aligning values of practitioners and journalists. Public Relations Review, 11, 34-42.

Kopenhaver, L., Martinson, D., \& and Ryan, M. (1984). How public relations practitioners and editors in Florida view each other. Journalism Quarterly, 61(4), 860-888. DOI:

$10.1177 / 107769908406100419$

Lancaster, P. (1992). Gentlemen of the press: The life and times of an early reporter, Julian Ralph of the Sun. New York: Syracuse University Press.

Lewis, J., Williams, A., Franklin, B., Thomas, J., \& Mosdell, N. (2008). The quality and independence of British journalism: Tracking the changes of 20 years. Research report. Cardiff School of Journalism, Media and Cultural Studies, Cardiff University, Wales. Retrieved from http://www.cardiff.ac.uk/jomec/research/researchgroups/journalismstudies/fundedprojects/qualitypre ss.html

Macnamara, J. (1993). Public relations and the media. Unpublished Master of Arts by research thesis, Deakin University, Geelong, Vic, Australia.

Macnamara, J. (2012). Journalism and public relations: Unpacking myths and stereotypes. Australian Journalism Review, 34(1), 33-50.

Matchett, S. (2010, July 14). The profession that dare not speak its name. The Australian, Higher Education, p. 26. Retrieved from http://www.theaustralian.com.au/higher-education/the-professionthat-dare-not-speak-its-name/story-e6frgcjx-1225891321598

McChesney, R. (2013). Digital disconnect: How capitalism is turning the internet against democracy. New York, NY: The Free Press.

McCorkindale, T. (2010). Can you see the writing on my wall? A content analysis of the Fortune 50's Facebook social networking sites. Public Relations Journal, 4(3), 1-13.

Merkel, B., Russ-Mohl, S., \& Zavaritt, G. (Eds.). (2007). A complicated, antagonistic and symbiotic affair: Journalism, public relations and their struggle for public attention. Lugano, Switzerland: Giampiero Casagrande.

Moloney, K. (2006). Rethinking public relations: PR propaganda and democracy ( $2^{\text {nd }}$ ed.). New York, NY: Routledge.

Parker, J. (2011, May 15). The dark side inside. The Failed Estate, blog post. Retrieved from http://thefailedestate.blogspot.com.au/2011/05/dark-side.html

Pew Research Center. (2013). The state of the news media 2013. Washington, DC: Pew Research Center Project for Excellence in Journalism. Retrieved from http://stateofthemedia.org/2013

PQ Media. (2013). PR media global product placement spending forecast 2012-2016. Retrieved from http://www.pqmedia.com/globalproductplacementforecast-2012.html

Punch, K. (1998). Introduction to social research: Quantitative and qualitative approaches. London, UK: Sage. 
Reichheld, F. (2008). The ultimate question: Driving good profits and true growth. Boston, MA: Harvard Business School Publishing.

Ryan, M., \& Martinson, D. (1984). Ethical values, the flow of journalistic information and public relations persons. Journalism Quarterly, 61(1), 27-34.

Ryan, M., \& Martinson, D. (1988). Journalists and public relations practitioners: Why the antagonism? Journalism Quarterly, 65(1), 131-140.

Ryan, M., \& Martinson, D. (1994). Public relations practitioners, journalists view lying similarly. Journalism Quarterly, 71(1), 199-211.

Sallot, L. (2002). What the public thinks about public relations: An impression management experiment. Journalism \& Mass Communication Quarterly, 79(1), 150-171. DOI: $10.1177 / 107769900207900111$

Sallot, L., \& Johnson, E. (2006). Investigating relationships between journalists and public relations practitioners: Work together to set, frame and build the public agenda, 1991-2004. Public Relations Review, 32, 151-159. DOI: 10.1016/j.pubrev.2006.02.008

Sallot, L., Steinfatt, T., \& Salwen, M. (1998). Journalists' and public relations practitioners' news values: Perceptions and cross-perceptions. Journalism and Mass Communication Quarterly, 75, 366-377.

Salter, L. (2005). The communicative structures of journalism and public relations. Journalism, 6(1), 90-106. DOI: 10.1177/1464884905048954

Sha, B. (1996, May). Does feminisation of the field make public relations more ethical? Paper presented to the International Communication Association Annual Conference, Chicago, IL.

Shin, J., \& Cameron, G. (2003). The potential of online media relations to address false consensus between source and reporter: A co-orientational analysis of PR professionals and journalists in Korea. Journalism \& Mass Communication Quarterly, 80(3), 583-602.

Shoemaker, P., \& Reese, S. (1996). Mediating the message: Theories of influence on mass media content. White Plains, NY: Longman.

Siebert, F., Peterson, T., \& Schramm, W. (1954). Four theories of the press: The authoritarian, libertarian, social responsibility, and Soviet communist concepts of what the press should be and do. Urbana, IL: University of Illinois Press.

Sigal, L. (1973). Reporters and officials. Lexington, MA: D.C. Heath.

Sissons, H. (2012). Journalism and public relations: A tale of two discourses. Discourse \& Communication, 6(3), 273-294.

Smith, B. (2008). [Review of A complicated, antagonistic, symbiotic affair: Journalism, public relations and their struggle for public attention]. Journalism \& Mass Communication Quarterly, 85, 925-927.

Stauber, J., \& Rampton, S. (1995). Toxic sludge is good for you: Lies, damn lies and the public relations industry. Monroe, ME: Common Courage Press.

Stegall, S., \& Sanders, K. (1986). Co-orientation of PR practitioners and news personnel in education news. Journalism Quarterly, 63(2), 341-347. DOI: 10.1177/107769908606300215

Tilley, E., Hollings, J. (2008). Still struck in a 'love-hate relationship': Understanding journalists' enduring and impassioned duality toward public relations. in E. Tilley (Ed.), Power and Place: ANZCA 2008: Refereed proceedings of the Australian and New Zealand Communication Association Conference 2008, 9-11 July, Massey University, Wellington, New Zealand. Retrieved from http://www.anzca.net/conferences/past-conferences/35-anzca08.html

Turner, G. (2010). Public relations. In S. Cunningham \& G. Turner (Eds.), The media and communications in Australia ( $3^{\text {rd }}$ ed., pp. 207-216). Crows Nest, NSW: Allen \& Unwin.

vanSlyke Turk, J. (1986). Public relations' influence on the news. Newspaper Research Journal, 7(4), 25-26.

Walker, S. (1999). City editor. Baltimore, IL: The Johns Hopkins University Press.

Wasserman, T. (2013, September 26). Why native advertising is the opposite of porn. Mashable, Business. Retrieved from http://mashable.com/2013/09/25/native-advertising-porn/

White, C., \& Shaw, T. (2005, August). Portrayal of public relations in mass communication textbooks. Paper presented at the Association for Education in Journalism and Mass Communication, San Antonio, Texas.

Whitney, D., Fritzler, M., Jones, S., Mazzarella, S., \& Rakow, L. (1980). Geographic and source biases in network television news. Journal of Broadcasting \& Electronic Media, 33(2), 159-174. 
Wilcox, D., \& Cameron, G. (2006). Public relations: Strategies and tactics (8 ${ }^{\text {th }}$ ed.). Boston, MA: Pearson Education/Allyn \& Bacon.

Wilson, D., \& Supa, D. (2013). Examining modern media relations: An exploratory study of the effect of Twitter on the public relations-journalist relationship. Public Relations Journal, 7(3), 1-20.

Witschge, T., Fenton, N., \& Freedman, D. (2010). Protecting the news: Civil society and the media. London, UK: Goldsmiths Leverhulme Media Research Centre, University of London. Retrieved from http://www.carnegieuktrust.org.uk/getattachment/1598111d-7cbc-471e-98b4dc4225f38e99/Protecting-the-News--Civil-Society-and-the-Media.aspx

Wouters, M. and P. de Pelsmacker. 2010. Brand placement in scripted and non-scripted Belgian and US programs on Belgian television. Journal of Marketing Communications, 17 (5), 299-318. DOI: 10.1080/13527261003600421

Wright, D. (2005). We have rights too: Examining the existence of professional prejudice and discrimination against public relations. Public Relations Review, 31(1), 101-109.

Wright, D., \& Hinson, M. (2009). Examining how public relations practitioners actually are using social media. Public Relations Journal, 3(3). Retrieved from http://www.prsa.org/Intelligence/PRJournal/Summer_09/

Zawawi, C. (1994). Source of news: Who feeds the watchdogs? Australian Journalism Review, 16(1), 67-72.

Zolotow, M. (1949, December 10). The great bamboozler. Saturday Evening Post, p. 22.

\section{Reference:}

Macnamara, J. [2014, In print]. Journalism-PR relations revisited: The good news, the bad news, and insights into tomorrow's news. Public Relations Review.

http://dx.doi.org/10.1016/j.pubrev.2014.07.002

* Jim Macnamara PhD, FPRIA, FAMI, CPM, FAMEC is Professor of Public Communication at the University of Technology Sydney, a position he took up in 2007 after a 30-year professional career spanning journalism, public relations and media research. He is the author of 15 books including Public Relations Theories, Practices, Critiques (Pearson Australia, 2012), The $21^{\text {st }}$ Century Media (R)evolution: Emergent Communication Practices (Peter Lang, New York, 2010, $2^{\text {nd }}$ edition 2014), and Journalism and PR: Unpacking 'Spin', Stereotypes and Media Myths (Peter Lang, New York, 2014).

1 General identification of interviewees by title and organization name or description, without individual names, is used for consistency where permission was granted.

2 Both interviewees quoted here are women and their comments were made and interpreted as reflections of the marketplace, not sexism. 